Marquette University

e-Publications@Marquette

Marketing Faculty Research and Publications

Marketing, Department of

$1-1-2016$

\title{
On the Nature of "Good" Goods and the Ethical Role of Marketing
}

Gene R. Laczniak

Marquette University, eugene.laczniak@marquette.edu

Nicholas J. C. Santos

Marquette University, nicholas.santos@marquette.edu

Thomas A. Klein

The University of Toledo

Accepted version. Journal of Catholic Social Thought, Vol. 13, No. 1 (Winter 2016): 63-81. DOI. (C) 2016 Philosophy Documentation Center. Used with permission. 


\title{
On the Nature of "Good" Goods and the Ethical Role of Marketing
}

\author{
Gene R. Laczniak \\ Marketing Department, Marquette University \\ Milwaukee, WI \\ Nicholas J.C. Santos \\ Marketing Department, Marquette University \\ Milwaukee, WI \\ Thomas A. Klein \\ Marketing Department, University of Toledo \\ Toledo, $\mathrm{OH}$
}

"The vocation of a businessperson is a genuine human and Christian calling. Its importance in the life of the Church and the world economy can hardly be overstated." Vocation of the Business Leader, $\S 6$

\section{Introduction}

The purpose of this essay is to elaborate on an important section of a document titled, Vocation of the Business Leader, published by the Pontifical Council for Justice and Peace. ${ }^{1}$ Subtitled "A 
Reflection," this document is an 87 paragraph, 13,000 word (in English) statement about the ideals of business leadership as inspired by Christian values and ethics. It was sponsored by Peter K.A. Cardinal Turkson and Bishop Mario Toso in consultation with assorted educators, theologians, economists, and philosophers. The document developed from reflections and discussions on Pope Benedict XVI's social encyclical Caritas in Veritate, particularly a seminar organized by the Pontifical Council for Justice and Peace in February 2011.2 As such, it extends Caritas in Veritate, especially with regard to economics and business. ${ }^{3}$

The direct purpose of this Roman Catholic statement is to motivate business leaders "to engage the contemporary economic and financial world in light of the principles of human dignity and the common good." 4 The commentary that follows is a pragmatic extension concerning how business managers might make their product and service decisions more ethical. A supporting theme involves how marketing ethics can contribute to the societal common good by way of responsible product management, especially as it applies to economically disadvantaged consumers.

This reflection on the characteristics of business vocation was intended to be a "an educational aid" to stimulate deeper thinking among Christian business managers, particularly those who would conceive of their managerial work as a spiritual calling-that is, an economic vocation that should always respect human dignity and strive to contribute to the common good. ${ }^{5,6}$ All business leaders of goodwill are specifically urged to do three things: (a) use their skills to address genuine human needs via "good" products and services, (b) organize productive and meaningful work, and (c) to create wealth and prosperity in a sustainable manner. ${ }^{7}$ To do this, business leaders are exhorted to cultivate practical wisdom, which largely involves "institutionalizing effective and just practices which foster right relationships with stakeholders."8 A goal of our commentary is to suggest some of the "right relationships with stakeholders" that can produce the best mix of goods and services that help develop a flourishing society. 
It is important to note that, while the Pontifical Council for Justice and Peace, a Catholic Church administrative entity, seeks to put forward practical principles, it explicitly recognizes that "It is not the place of the Church to prescribe in detail the actions of business leaders. Prescription is the work of practitioners, and is largely carried out by lay people." ${ }^{\prime \prime}$ To that end, this normative commentary is intended to be a further elaboration on the first vocational aspiration listed above, namely, the notion that "the Christian business leader serves the common good by creating goods which are truly good and services which truly serve." 10 That is, business leaders discharge their role by addressing genuine human needs via the products they produce and distribute. We will leave it to others to comment in further detail about the nature of meaningful work and the sustainability of economic ventures although all of these factors are connected in helping to shape a socially responsible business organization.

To put it another way, we explore in this commentary, "What is the nature and role of business organizations and its managers in serving the common good of society via the production and distribution of goods and services?" Or, yet another query variation, "What does providing 'good goods,' as labeled in this document, entail for business firms wishing to operate ethically and responsibly?" Our commentary draws heavily on previous articles we have published. But in the original articles cited, as with most scholarship, we have footnoted heavily the sources from where we drew our authority and inspiration. In this essay, however, we reference predominantly our own work, not because we are the "final word" on these matters but because these are issues about which we have previously opined in some detail. Our essay will be composed of three main parts:

1. The essential role of the marketing function in the provisioning of goods and services in a market economy and the importance of ethical marketing to positive societal outcomes.

2. The connection of the seminal principles inherent in Catholic social thought to the conduct of ethical marketing, especially in the oversight of necessary products.

3. The usefulness of elements embodied in a framework called the integrative justice model (or IJM) in helping organize the steps required for corporations to provide products that lift up 
disadvantaged consumers as well as develop sustainable economic communities.

But before turning attention to these main points, it is necessary to venture some brief commentary on the nature and scope of "good" goods.

\section{Defining "Good" Goods}

Quoting the Compendium of the Social Doctrine of Catholic Church, it is stated: "Businesses should be characterized by their capacity to serve the common good of society through the production of useful goods and services."11 The "common good" is defined as "the sum total of social conditions which allow people, either as groups or as individuals, to reach their fulfillment more fully and more easily."12 The document specifically mentions as essential the creation and improvement of useful outputs such as medicine, communications, credit, food, and energy among others. But what are truly "good" goods and "bad" goods? Goods and services "should meet authentic human needs . . . [that] have clear social value."13 Favorably mentioned in this context are life-saving medical devices, microfinance, education, social investments, healthcare, fair-trade products, and affordable housing. Further on, we also read about (bad) goods and services that are "detrimental to human wellbeing"; mentioned here as socially harmful goods are non-therapeutic drugs, pornography, gambling, and violent video games-each of which contributes to the "creation of futilities" that are "useless" or "injurious" to most persons. ${ }^{14}$

For the moment, we leave aside the issue of "public goods" such as roads, bridges, telecom infrastructure, and a working legal system. The document also speaks to the central importance and ethical instrumentality of such helpful public goods. ${ }^{15}$ Since these types of goods are most often in the domain of government ${ }^{16}$ and, since the document focuses on business leaders, we concentrate our commentary on private goods. This is not to deny that the provision of these goods is often a collaborative effort among private businesses, nongovernmental organizations, and government entities. That said, it is possible, as argued by the renowned economist John Kenneth 
Galbraith in The Affluent Society, that certain market arrangements might discriminate so much in favor of private goods that needed public goods are attenuated for the general society, and to their collective detriment. ${ }^{16}$ But that is a topic for another essay.

Given the earlier remarks regarding private goods, it is clear that this perspective posits some truly "good" goods that are needed and some fundamentally "bad" products to be avoided. Certainly, an executive who devotes his life to selling tobacco products that cause cancer (and death) is not living the vocation of a Christian business leader. Similarly, the manager who oversees a social agency providing special service for the severely disabled is actualizing her vocation and directly contributes to the empowerment of others lives. But such stark distinctions, while of some worth because they anchor the ends of the spectrum, fail to categorize the majority of products and services that fall somewhere between. One might stipulate that most products are neither virtuous nor evil but somewhere between. Are alcoholic beverages a "bad" product even though when used in moderation they might provide a significant health enhancement? Are weaponized drone aircraft a "good" product because they kill persons that some government classifies as "terrorist" albeit with sometimesinnocent collateral damage?

In business, most products can be used (as well as promoted/distributed) for good or evil. Opiates, a product with negative connotations, can relieve pain. Water, a product with positive connotations, might be utilized in simulated drowning torture. Thus, it is often not the product itself, but rather the audience to whom that product is directed, how it is market-positioned for its functionality, the way it is promoted and distributed, and whether it is fairly priced that establishes its inherent "rightness" or "goodness." All these added dimensions are the realm of the marketing function and thus, the ethicality of goods and services in a complex economy cannot be understood without addressing the question of proper (i.e., ethical) marketing. 


\section{Marketing: The "Provisioning" Function of Business Activity and its Centrality to Ethical Products}

The official definition of marketing is as follows: Marketing is the activity, set of institutions, and processes for creating, communicating, delivering, and exchanging offerings that have value for customers, clients, partners, and society at large. ${ }^{17}$ Clearly, this definition, which emphasizes marketing as the business function that coordinates the full value proposition offered for sale by firms to society, suggests that the issue of "product management" cannot be thoughtfully deconstructed without understanding marketing, as an umbrella concept. It follows that "good" products and services cannot be judged without reference to "ethical marketing."

Fortunately, a great deal has been written about ethical marketing including how marketing must be normatively practiced in order to contribute to the greater societal good. ${ }^{18}$ There are even detailed essays about how Catholic social thought can uniquely help nurture the ethical practice of marketing. ${ }^{19}$ We will touch upon all of this below.

Of course, to assert that ethical marketing is important to the vocation of business leadership is very different than getting the majority of marketing managers to agree with specifically identified ethical ideals. In the business world, most marketers would assert that they already are sufficiently ethical and contribute significantly to society's good via the essential utility-enhancing functions they perform. But that aggregate self-understanding can be misleading. It is a perception, regarding the fundamental goodness of marketing activities, which is rooted in a narrow economic ideology-one with its justification typically cited to the intellectual legacies of Adam Smith ${ }^{20}$ and Milton Friedman. ${ }^{21}$ This minimalist "defense of marketing" as positive social force plays out in concert with the following narrative:

Free and unregulated markets are always the most efficient allocation mechanism for goods and services. Ethics is a very relative and debatable topic and thus, the only truly agreed upon moral behaviors are codified in law. Furthermore, the so- 
called "common good" is impossible to define. Thus, the purpose of marketing is best served if business firms attempt to maximize wealth for owners by providing whatever is desired. If Business gets involved in distracting social philanthropy or cultural judgments (often controversial), because such activism costs money, this will subtract from profits. Therefore, business managers should focus on the production, promotion, and distribution of products constrained only by the rule of law. A discriminating public will anoint winning products and a discerning and competitive marketplace will winnow out improper practices. Moral duties not enshrined by the law are a fiction created in the moral prejudices of individuals. ${ }^{22}$

The above "stereotypical" demarcation of proper marketing, anchored by a supreme "amorality" of economic utilitarianism and market outcomes (constrained only by law), can be shown as grounded in a cartoonish understanding of Smith and Friedman; but this too is a tangent best left for another day. Nevertheless, such acceptance of values-free marketing is one that many MBA students would subscribe to based upon the classroom experience of our authors. It is very much the kind of thinking that has been shaped by an exclusive micro perspective-seeing things only from the standpoint of the corporation for which one works. And, it is this kind of thinking that this document cautions against when it speaks to the destructiveness of a "financialization of the economy," the prospect that "Shareholder value has become virtually the sole metric by which business leaders determine their performance and their worth." 23 Similarly, Vocation of the Business Leader warns about a loose and relative business ethics that is "contradictory to the Church's social doctrine" and that might lead to "exploitation" as well as any corporate responsibility efforts "being instrumentalized." 24 The egoistic me-first "objectivism" of writers such as Ayn Rand certainly comes to mind in this context. ${ }^{25}$ In the purview of a business leader's vocation, this is a perspective that is clearly at odds with the servant leadership model. ${ }^{26}$

So what manifestation should ethical marketing take in order to assure that the likelihood of beneficial products and services for society is enhanced?

Laczniak and Murphy reviewed 50 years of marketing ethics research and scholarship while searching for the universal propositions 
of normative ethical marketing. ${ }^{27}$ They identify seven basic propositions. Recalling the focus of Vocation of the Business Leader on the centrality of "human dignity," the first normative proposition of the Laczniak and Murphy thesis-"Ethical Marketing puts people first" is worth (partially) quoting: "The marketing system should always be of service to people... People should never be treated merely as cogs in the marketing system, whether they are customers, employees, suppliers, distributors or some other stakeholder" (157). The writers position this human dignity grounded proposition at the center of their constellation of normative propositions for ethical marketing.

Murphy, Laczniak, and Prothero define ethical marketing as "practices that emphasize transparent, trustworthy, and responsible personal and/or organizational marketing policies and actions that exhibit integrity as well as fairness to consumers and other stakeholders." 28 Obviously, the essential language of this definition includes some very broad terms and begs the question of how precisely transparency, respect, responsibility, and fairness are defined, as well as how wide a net of possible stakeholder interests are covered. However, marketers committed to ethical practice have not been silent on these problems; marketing practitioners can find considerable professional guidance in documents such as the American Marketing Association Statement on Ethics. ${ }^{29}$ A perusal of the Statement indicates that each of these "lofty" terms have been defined and illustrated with specific marketing practices that are to be encouraged or discouraged. This includes articulated duties toward the welfare of multiple stakeholders and adherence to moral norms such non-malfeasance and non-deception of stakeholders, especially consumers.

Recognition of ethics at the micro-organizational level is a necessary but not sufficient condition to help generate the "good" goods desired in Vocation of the Business Leader. To enhance the likelihood that business organizations will provide an assortment of goods and services that contribute to the flourishing of a fair and healthy society, it is imperative that a macromarketing perspective be kept in mind. This view contrasts with the micro-view of marketing, which perceives its function as working best if each individual firm simply seeks to optimize company outcomes. It is accurate to contend 
that market-facing exchanges are effective most of time. In fact, here is what Vocation of the Business Leader says about that: "When business and markets as a whole are functioning properly . . . they make an irreplaceable contribution to the material and even spiritual well-being of humankind." ${ }^{30}$ However, marketing efficiency is not the same thing as market equity or fairness. Markets are often imperfect. Unexpected and/or secondary outcomes flowing from the interaction of markets, marketing, and society are best analyzed from a macro framework. This involves taking into account broader macromarketing perspectives that supersede a micro-firm focus. Inherent in this perspective are propositions (drawn from the Macromarketing Society Website)31 such as:

- Markets, marketing, and society are connected into a networked system that shapes economic outcomes as well as global human welfare-now and well into the future;

- The nature and structure of market operations are decisive; free, competitive markets have many seminal advantages but constraints and controls are often necessary and these can take many forms;

- The discipline of Marketing is central to the provisioning of society's needs via its focus on the co-creation of value propositions and the facilitation of exchange;

- The nature of the macromarketing system shapes quality-of-life, stakeholder wellbeing, environmental sustainability, and general societal flourishing;

- Political ideologies, normative ethics, technology, and cultural factors are embedded at all levels of the marketing system.

With an eye to enlightened choices in products and services, ethical business leadership requires that such macro viewpoints be considered and analyzed because marketing actions have major ramifications for society. As Murphy and Laczniak conclude: "Marketers are responsible for whatever they intend as a means or end." 32

\section{Catholic Social Thought and the Ethical Practice of Marketing}

The upshot of the articulated normative propositions and their macromarketing connections is that marketing practices are never "value neutral." Again, those who claim that market machinations 
alone should shape economic outcomes are practicing a philosophical form of economic determinism not logically rooted in any deontological ethical theory. Vocation of the Business Leader advocates something quite different than the value neutrality of market imperatives: "An important part of the business leader's vocation is practicing ethical social principles while conducting the rhythms of the business world."33 This document is a product of the Catholic social tradition, the everevolving social commentary on the principles of Catholic social thought. Once more, the marketing literature has already weighed in on Catholic social thought and its bridges to marketing practice.

Klein and Laczniak, using key principles of Catholic social thought (human dignity, common good, subsidiarity, preference for the poor and vulnerable, workers' rights, solidarity, and environmental stewardship) $)^{34}$ as an ethical springboard, set forth the many pragmatic implications of Catholic social thought for the ethical conduct of marketing. ${ }^{35}$ The authors stress in their writings that most of these managerial deductions concerning ethical marketing practice could be derived from non-sectarian ethical theory as well as from Church doctrine. If true, that observation only adds to the managerial appeal of this approach since it increases the likelihood that more business leaders would seriously consider such religious values-inspired approaches for ethical guidance. In pedagogical fashion, Klein and Laczniak literally specify "A to Z" guidelines for responsible marketing in major categories (products, promotion, pricing, distribution, globalization, and public policy), relating each guideline to applicable principles. Some of these recommendations speak directly to the question of "good" goods, while others, somewhat more indirectly. For example, included in the list of ethical desirata are tactical recommendations such as:

- Marketers should place a high priority on product safety.

- Marketers should refrain from promotions and pricing schemes [for their products and services] that take advantage of information asymmetries and/or buyer weaknesses.

- Marketers must recognize special obligations to children and adolescents as well as those whose addictions may be stimulated by [product] promises and images projected over the worldwide web. 
In that article, Klein and Laczniak also make it clear that such lists, inspired by Catholic social teachings, do not replace sound and dynamic business judgment, but that they can nevertheless keep ethical considerations "front and center" as managers try to responsibly discharge their economic duties. Yet, managerial guidelines are only part of the issue; markets must be structured so that they are both efficient and fair to all participants. In a follow-up article to the one just noted, Laczniak and Klein write:

In the Catholic social tradition, the understanding of a proper market mechanism is one governed both by the mutual interests of its participants as well as one having trust among market participants; that is, the market should be perceived as fair to all interests. Thus, drawing on the concept of distributive justice, [business actions must] emphasize the importance of transparency and cooperation, taking into account differences in power among the parties in the exchange and providing due regard for any vulnerabilities that those participants may bring to market transactions. One challenge for business executives will be to establish what elements constitute a "just and fair" marketplace for their economic sector of activity. ${ }^{36}$

Vocation of the Business Leader, reflecting this view, urges that there be a special effort to provide useful goods and services that are in "solidarity with the poor."37 The nature of the constructive engagement required for ethical marketers to follow this imperative and to serve disadvantaged consumers is now addressed.

\section{The Integrative Justice Model for Ethically Serving Impoverished Consumers}

The objective for marketers to ethically handle their professional responsibilities concerning the promotion, pricing, and distribution of products can be viewed as an "embedded" or inherent morality. That is, by license of their professionalism and/or adherence to their vocational duties, managers who are inspired by Christian religious values should naturally strive to be ethical marketers. But Vocation of the Business Leader also asks something exceptionally beyond this. It invites a proactive ethics regarding the oversight of certain "good" goods marketing by business executives. Managers are challenged to 
be "in solidarity with the poor" and to be actively forthcoming in their service and responses to these market segments. ${ }^{38}$ Too often-given shortcomings in adequate product/service options, financial sophistication, market access, or economic leverage-the poorest, most vulnerable consumers are ripe targets for rapacious exploitation. ${ }^{39}$ Regarding such vulnerable market segments, especially the most impoverished "bottom-of-the-pyramid" consumers, the document asserts: "The Christian business leader is alert for opportunities to serve these otherwise underserved populations and sees this not only as proper social responsibility but as a great business opportunity." 40

Fortunately, there is once again ready-made commentary that speaks directly to this issue in marketing terms. Santos and Laczniak have put forward an Integrative Justice Model for marketing to the poor (see Figure 1). ${ }^{41}$ According to the authors, the model was so named not because it analyzed all forms of justice regarding the treatment of the poor, but rather due to its identification of a series of elemental perspectives that, taken together, would provide exchange situations that would be fairer to poor and vulnerable consumers. The intent of the Santos and Laczniak paper was mainly to illustrate a philosophical derivation of essential characteristics that might level the playing field for exploited "poor" or "vulnerable" consumers. The integrative justice model postulations were grounded in moral philosophy theories and frameworks of corporate social responsibility, giving them greater validity for managers of all faiths-or none. Utilizing a process inspired by Bishop, ${ }^{42}$ the key elements of this model for ethically marketing to the impoverished were found to be:

1. Authentic engagement with impoverished consumers without exploitative intent;

2. Co-creation of value with all customers, especially those who are impoverished or disadvantaged;

3. Investment in future consumption without endangering the environment;

4. Genuine interest representation of all stakeholders, particularly impoverished customers; and

5. Focus on long-term profit management rather than on shortterm profit maximization. 
NOT THE PUBLISHED VERSION; this is the author's final, peer-reviewed manuscript. The published version may be accessed by following the link in the citation at the bottom of the page.

Examples of companies that seem to model some of these elements were also discussed in that paper. Firms that follow some or much of this protocol when engaging poor or vulnerable markets will generate customer empowerment, longer term relationships, sustainable enterprises, and a more fair and ethical marketplace

In a companion piece, Santos and Laczniak further described how each of these elements could be seen as perfectly consistent with key principles of Catholic social thought. ${ }^{43}$ "Authentic engagement" and "Co-creation" are shown to be extensions of the principle of Human Dignity; "Investment in Future Consumption" is nested in the principle of Preference for the Poor and Vulnerable as well as the principle of Stewardship; "Representation of all stakeholders" is a logical extension of the principle of Solidarity; and, given opportunities for interactions among interdependent interests, "Long term profit" can be seen as an economic manifestation of the principle of the Common Good.

The consistency of the integrative justice framework with Catholic social thought is intellectually and even theologically interesting. However, one might well question how that approach can actually advance the objective of Vocation of the Business Leader in identifying specific managerial steps to be used when engaging those that have the least. Santos and Laczniak attempt to answer precisely this question by examining various real world cases featured in the business literature where companies innovatively reach out to Bottomof-the-Pyramid buyers or other impoverished segments in order to promote more fair exchange. ${ }^{44}$ Well-known examples such as Grameen Bank in South Asia, Casa Bahia in Brazil, and Toyota University in India, as well as some less well-known experiments, are mined for their basic lessons. These approaches are then reclassified according to the elements of the integrative justice model and listed as a set of idealized tactical and strategic recommendations (See Appendix I). In essence, Appendix I represents a playbook, inspired by actual exemplary practices and organized according to those elements, for how business leaders might ethically market products and services to the most vulnerable consumers. As a review of the conclusions that Appendix I suggests, businesses concerned with fair treatment of the poor are asked to take a host of actions, including the following:

Journal of Catholic Social Thought, Vol 13, No. 1 (Winter 2016): pg. 63-81. DOI. This article is (c) Philosophy Documentation Center and permission has been granted for this version to appear in e-Publications@Marquette. Philosophy Documentation Center does not grant permission for this article to be further copied/distributed or hosted elsewhere without the express permission from Philosophy Documentation Center. 
NOT THE PUBLISHED VERSION; this is the author's final, peer-reviewed manuscript. The published version may be accessed by following the link in the citation at the bottom of the page.

- Encourage employee voluntarism in impoverished areas in order to build an empathy and understanding that will make exploitation less likely;

- Constantly seek input from potential consumers in vulnerable markets in order to increase the probability of co-creation;

- Invest in the capabilities of local consumers to help improve the chances that they can continue to be buyers long into the future;

- Ensure the product and services support materials are easily understood by the "disadvantaged" market segment being served;

- View impoverished markets not mainly as profit centers but rather as future sources of ideas, innovation, and satisfaction that can be used for competitive advantage.

\section{Summary and Conclusion}

Once again, we revisit the main purpose of our commentary. Vocation of the Business Leader asks business leaders to demonstrate the vocational task of producing the "good" products and services that will help enhance a better and more equitable society. It further asks managers and management educators to reflect on the pragmatic steps that may help business leaders of goodwill to achieve this goal. ${ }^{45}$ To that end, our thesis is that the planning, analysis, and oversight of societally affirming products are synonymous with ethical marketing. Moreover, many normative ethical recommendations and strategies have been ventured in the marketing and management literature that reinforces the objective of "meeting the needs of the world through goods and services" and improving the quality of people's lives. ${ }^{46}$ Specifically, in order to help renew business leader reflection about their vocation, we offered the following:

- The American Marketing Association's Statement of Ethics, which specifies the ethical norms and values desired of all marketing professionals; ${ }^{47}$

- Key principles of Catholic social thought most applicable to business situations; 48

- The logical implications of Catholic social thought that might be deduced to help assure and improve the ethical practice of product and service marketing; ${ }^{49}$ 
NOT THE PUBLISHED VERSION; this is the author's final, peer-reviewed manuscript. The published version may be accessed by following the link in the citation at the bottom of the page.

- An integrative justice model for fairly marketing to poor and vulnerable populations that can be sketched out using Catholic social thought principles and applied practical wisdom (Figure 1);

- The strategies and tactics to vitalize the integrative justice model,

- based on real world case examples, which can be assembled for

- businesses engaging the poor (Appendix I).

In short, arrays of specific managerial precepts that illustrate the practices connected with ethical product management are compiled in this essay. We hope one outcome of this exercise is a more complete and nuanced meaning of one of the abiding themes of Vocation of the Business Leader-provisioning for a flourishing society via products and services. But in the end, we should remember that it is always the moral imagination ${ }^{50}$ that flows from a thoughtful examination of conscience by business leaders that most directly shapes progress toward the common good:

Ethical social principles, illuminated for Christians by the Gospel, provide direction for good businesses, but the navigation falls to the seasoned and intelligent judgment of virtuous business leaders who can wisely manage the complexity and tensions arising in particular cases. ${ }^{51}$

\section{Appendix I. Strategies and tactics for marketing to impoverished consumers according to the Integrative Justice Model (IJM)}

The following decision principles based on an authentic engagement with customers with non-exploitative intent can be proposed:

(a) A business firm should strive to develop trust with its customers at all levels.

(b) A business firm ought to develop its competitive advantage through a process of collaboration rather than focusing on eliminating competition.

(c) A business firm ought to take a long-term perspective that holds that improving the quality of society and the environment is to the benefit of all. 
NOT THE PUBLISHED VERSION; this is the author's final, peer-reviewed manuscript. The published version may be accessed by following the link in the citation at the bottom of the page.

(d) A business firm ought never to take advantage of the relative weaknesses of its customers. Instead, it should make maximum efforts, using its own relative strengths to relieve these shortcomings, so that the consumer experience is enhanced. In effect, companies ought to build a trustworthy reputation for fair dealing, dependability, and continuous care.

(e) A business firm ought to encourage employee volunteering particularly in impoverished neighborhoods.

(f) A business firm should foster social sustainability while ensuring profitability in the long run.

(g) A business firm should support the formalization of consumer rights that guarantee safety, redress, sufficient information, and other basic requirements of exchange fairness.

The following decision principles based on co-creation of value with exchange partners can be proposed:

(a) Instead of autonomously positing what constitutes value for impoverished consumers, a business firm ought to involve such consumers in the value-creation process itself.

(b) A business firm ought to use its resources to ensure that its fairly priced offering proposes what is of best economic value for its targeted impoverished customers.

(c) A business firm should engage in a co-creation process that fosters sustained partnerships and develops mutual trust with impoverished customers that extends beyond the consumption of the product or service.

(d) A business firm ought to leverage local innovativeness and actively seek ways in which its impoverished customers can participate in the value co-creation process.

(e) A business firm should constantly seek input from its impoverished customers either directly or through observation and should incorporate this feedback into its decision-making processes.

(f) A business firm should consider ways in which its impoverished customers can be given an ownership stake in the company.

(g) A business firm ought to partner with local NGOs so as to leverage the expertise, goodwill, and network of the NGO in a mutually advantageous manner.

(h) A business firm ought to collaborate with the local communities in which it operates so as to tap into the social network they constitute. 
NOT THE PUBLISHED VERSION; this is the author's final, peer-reviewed manuscript. The published version may be accessed by following the link in the citation at the bottom of the page.

The following decision principles based on an investment in future consumption can be proposed:

(a) A business firm ought to invest in research and development that is aimed at developing innovations for impoverished markets that are both socially beneficial and environmentally friendly.

(b) A business firm should strive to increase the capabilities of impoverished segments so as to ensure that these impoverished segments can better participate in the market economy.

(c) A business firm ought to pay its employees a living wage so as to ensure that they can contribute to the overall economy of which the firm is also a part.

(d) In the conception, production, and delivery of goods or services, a company should strive to ensure that the ecological footprint is minimized.

(e) In keeping with an emerging perspective in impoverished markets, a business firm ought to afford access to products and services (e.g., leasing or sharing) rather than focusing on ownership of these.

The following decision principles based on an interest representation of all stakeholders can be proposed:

(a) A business firm ought to consider what matters to its stakeholders and is to their advantage. Further, the firm ought to demonstrate through business policies and ethical audits that such accommodations have indeed taken place.

(b) A business firm ought to consider its impoverished customers as primary stakeholders as these customers have a continuing and essential interest in the firm and are also vital to the growth and survival of the business initiative once a commitment to target this segment is made.

(c) A business firm should encourage its employees to have a firsthand experience of the real world of low-income consumers.

(d) A business firm should ensure that decisions, actions, and procedures that are promulgated do not further disadvantage impoverished customers.

(e) A business firm ought to engage in dialogue with impoverished customers regarding its products and services

Journal of Catholic Social Thought, Vol 13, No. 1 (Winter 2016): pg. 63-81. DOI. This article is @ Philosophy Documentation Center and permission has been granted for this version to appear in e-Publications@Marquette. Philosophy Documentation Center does not grant permission for this article to be further copied/distributed or hosted elsewhere without the express permission from Philosophy Documentation Center. 
NOT THE PUBLISHED VERSION; this is the author's final, peer-reviewed manuscript. The published version may be accessed by following the link in the citation at the bottom of the page.

so as to ensure a greater likelihood of the customers' interests being taken into account.

(f) A business firm ought to make efforts to understand the difficulties and constraints faced by impoverished customers and try to alleviate these so as to enhance the overall consumer experience. This strategy might involve investing in education, health care, sanitation, and access to credit, which expand the capabilities of the impoverished consumers and enable a richer firm-consumer relationship.

(g) A business firm ought to include consumer education and counseling as part of its marketing strategy to ensure better representation of the long-term interests of its impoverished customers and to enable the customers to make better informed choices.

(h) A business firm ought to develop and promote products and services that are especially relevant to the impoverished market segment.

(i) A business firm ought to enable better access of impoverished customers to the market to enable them to better participate in the market economy.

(j) A business firm should make its products and services affordable, accessible, and available.

(k) A business firm should ensure that its impoverished customers easily understand the information about its products and services.

The following decision principles based on long-term profit management can be proposed:

(a) Instead of seeking to maximize financial returns in the short run, a business firm ought to aim at creating sustainable value in the long run.

(b) A company, consistent with its role as a social as well economic institution, ought to consider social goals as ends in themselves rather than as means to a financial end.

(c) A business firm ought to increase business success with a long-term perspective based on social, environmental, and financial returns.

(d) A business firm ought to view impoverished markets as sources of opportunity, innovation, and competitive advantage.

(e) A business firm ought to support local communities in their holistic development in terms of supporting education, health, sports, the arts, and so forth at a scale and focus befitting the local community and culture. 
NOT THE PUBLISHED VERSION; this is the author's final, peer-reviewed manuscript. The published version may be accessed by following the link in the citation at the bottom of the page.

\section{Notes}

${ }^{1}$ Pontifical Council for Justice and Peace, "Vocation of the Business Leader" (VBL), 2011, accessed November 14, 2013, http://www.stthomas.edu/cathstudies/cst/VocationBusinessLead /VocationTurksonRemar/VocationBk3rdEdition.pd.

${ }^{2} \mathrm{~A}$. M. Greenwall, "Vatican Releases 'The Vocation of the Business Leader,'" Catholic Online, April 29, 2012, accessed June 14, 2015, http://www.catholic.org/news/business/story.php?id=45927. ${ }^{3}$ For excellent commentaries on Caritas in Veritate with regard to economics and business see K. E. Goodpaster, "Goods That are Truly Good and Services that Truly Serve: Reflections on Caritas in Veritate," in Journal of Business Ethics 100, no. 1 (2011): 916; T. A. Klein and G. R. Laczniak, "Implications of Caritas in Veritate for Marketing and Business Ethics," in Journal of Business Ethics 112, no. 4(2013): 641-51; R. Puggioni, "Roman Catholic Perspectives on Social Justice, Economics, and the Market: Elements for a Debate from Benedict XVI's Caritas in Veritate," in Journal of Catholic Social Thought 12, no. 1 (2015): 109-42.

${ }^{4} \mathrm{VBL}$, Foreword.

${ }^{5}$ Ibid., §37.

${ }^{6}$ By tradition, quotations from Church documents like VBL often refer to their source paragraph because of the multiple languages into which they are translated. Hence, we commonly find citations such as "at (§13)" or "in (§74)." This article follows that convention.

${ }^{7} \mathrm{VBL}, \S 38$.

${ }^{8}$ Ibid., $\S 75$.

${ }^{9}$ Ibid., $§ 74$.

${ }^{10}$ Ibid., §41.

${ }^{11}$ Ibid., §41.

${ }^{12}$ Ibid., §34.

${ }^{13}$ Ibid., $\$ 41$.

${ }^{14}$ Ibid., $\S 42$.

${ }^{15}$ Ibid., §34. 
16]. K. Galbraith, The Affluent Society (Boston: Houghton Mifflin, 1958).

${ }^{17}$ American Marketing Association "Statement of Ethics" (2008), accessed August 20, 2015, $<$ https://archive.ama.org/Archive/AboutAMA/Pages/Statement \%20of\%20Ethics.aspx>.

${ }^{18} \mathrm{G}$. R. Laczniak and P. E. Murphy, "Normative Perspectives for Ethical and Socially Responsible Marketing," in Journal of Macromarketing 26, no. 2 (2006): 154-77; P. E. Murphy and G. R. Laczniak, Marketing Ethics: Cases and Readings (New Jersey: Prentice-Hall, 2006); P. E. Murphy, M. Obersader, and G. R. Laczniak, "Corporate Social Responsibility in Marketing: Normatively Broadening the Concept," in AMS Review 3 no. 2 (2013): 86-102.

${ }^{19}$ T. A. Klein and G. R. Laczniak, "Applying Catholic Social Teachings to Ethical Issues in Marketing," in Journal of Macromarketing 29, no. 3 (2009): 233-43; G. R. Laczniak and T. A. Klein, "Caritas in Veritate: Updating Catholic Social Teaching for Macromarketing and Business Strategy," in Journal of Macromarketing 30, no. 3 (2010): 293-96; G. R. Laczniak, T. A. Klein, and P. E. Murphy, "Updating Catholic Social Teaching for Responsible Marketing Strategy," in P. E. Murphy and J. F. Sherry, Marketing and the Common Good (London: Routledge, 2013), 105-18.

${ }^{20} \mathrm{~A}$. Smith, An Inquiry into the Nature and Causes of the Wealth of Nations (London: W. Strahan and T. Cadell, 1776).

${ }^{21} \mathrm{M}$. Friedman, Capitalism and Freedom (Chicago: University of Chicago Press, 1962).

${ }^{22}$ For an example of such argumentation see J. Gaski, "To Serve Man: A Marketing Manifesto (and an article that should not have been necessary)," in Journal of Public Policy \& Marketing 32, no. 1 (2013): 6-17.

${ }^{23} \mathrm{VBL}, \S 23$. ${ }^{24}$ Ibid., $§ 79$.

${ }^{25}$ A. Rand, The Virtue of Selfishness (New York: Signet Books, 1961).

${ }^{26}$ D. van Dierendonck, "Servant Leadership: A Review and Synthesis," in Journal of Management 37, no. 4 (2011): 1228-61; D. L. Parris and J. W. Peachey, "A Systematic Review of Servant 
Leadership Theory," in Journal of Business Ethics 113 (2013): 377-93.

${ }^{27}$ Laczniak and Murphy, "Normative Perspectives," 154-77.

${ }^{28}$ P. E. Murphy, G. R. Laczniak, and A. Prothereo, Ethics in Marketing: International Cases and Perspectives (London: Routledge, 2012).

${ }^{29}$ American Marketing Association, "Statement of Ethics." ${ }^{30} \mathrm{VBL}$, §2.

${ }^{31}$ The Macromarketing Society Welcome (n.d.), accessed August 20, 2015, http://macromarketing.org/.

${ }^{32}$ Laczniak and Murphy, "Normative Perspectives," 162.

${ }^{33} \mathrm{VBL}, \S 14$.

${ }^{34}$ Compendium of the Social Doctrine of the Church (Rome: Pontifical Council for Justice and Peace, 2005), accessed August 21, 2015, $<$ http://www.vatican.va/roman_curia/pontifical_councils/justpe ace/documents/rc_pc_justpeace_doc_20060526_compendiodottsoc_en.html>.

${ }^{35 K}$ lein and Laczniak, "Applying Catholic Social Teachings to Ethical Issues in Marketing."

${ }^{36}$ Laczniak and Klein, "Caritas in Veritate: Updating Catholic Social Teaching for Macromarketing and Business Strategy."

${ }^{37} \mathrm{VBL}, \S 43$.

${ }^{38}$ Ibid., §41.

${ }^{39}$ See G. R. Laczniak, "Distributive Justice, Catholic Social Teaching, and the Moral Responsibility of Marketers," in Journal of Public Policy \& Marketing 18, no. 1 (1999): 125-29.

${ }^{40} \mathrm{VBL}, \S 43$.

${ }^{41}$ N. J. C. Santos and G. R. Laczniak, "Marketing to the Poor: An Integrative Justice Model for Engaging Impoverished Market Segments," in Journal of Public Policy \& Marketing 28, no. 1 (2009): 3-15.

42]. D. Bishop, "A Framework for Discussing Normative Theories of Business Ethics," in Business Ethics Quarterly 10, no. 3 (2000): 563-92.

${ }^{43}$ N. J. C. Santos and G. R. Laczniak. "'Just' Markets from the Perspective of Catholic Social Teaching," in Journal of Business Ethics 89, no. 1 (2009): 29-38.

${ }^{44}$ N. J. C. Santos and G. R. Laczniak, "Marketing to the Base of the Pyramid: A Corporate Responsibility Approach with Case 
NOT THE PUBLISHED VERSION; this is the author's final, peer-reviewed manuscript. The published version may be accessed by following the link in the citation at the bottom of the page.

Inspired Strategies," in Business and Politics 14, no. 1 (2012): article 4, doi: 10.1515/1469-3569.1364. See also C. Gradl et al., "Understanding the Markets of the Poor: A Market System Approach to Inclusive Business Models," in P. Kandachar and M. Halme, Sustainability Challenges and Solutions at the Base of the Pyramid: Business, Technology and the Poor (Sheffield, UK: Greenleaf Publishing, 2008), 30-50.

${ }^{45} \mathrm{VBL}, \S 87$.

${ }^{46}$ Ibid., $\S 40$.

${ }^{47}$ American Marketing Association. "Statement of Ethics."

${ }^{48}$ Klein and Laczniak, "Applying Catholic Social Teachings to Ethical Issues in Marketing."

${ }^{49}$ Laczniak and Klein, "Caritas in Veritate: Updating Catholic Social Teaching for Macromarketing and Business Strategy."

${ }^{50}$ See P. H. Werhane, "Moral Imagination and Systems Thinking," in Journal of Business Ethics 38 (2002): 33-42. Werhane distinguishes moral imagination from moral reasoning and states that "moral imagination helps one to disengage from a particular process, evaluate that and the mindsets which it incorporates, and think more creatively within the constraints of what is morally possible" (34).

${ }^{51} \mathrm{VBL}, \S 59$.

Journal of Catholic Social Thought, Vol 13, No. 1 (Winter 2016): pg. 63-81. DOI. This article is (c) Philosophy Documentation Center and permission has been granted for this version to appear in e-Publications@Marquette. Philosophy Documentation Center does not grant permission for this article to be further copied/distributed or hosted elsewhere without the express permission from Philosophy Documentation Center. 
NOT THE PUBLISHED VERSION; this is the author's final, peer-reviewed manuscript. The published version may be accessed by following the link in the citation at the bottom of the page.

Figure 1. An Integrative Justice Model for Impoverished Markets

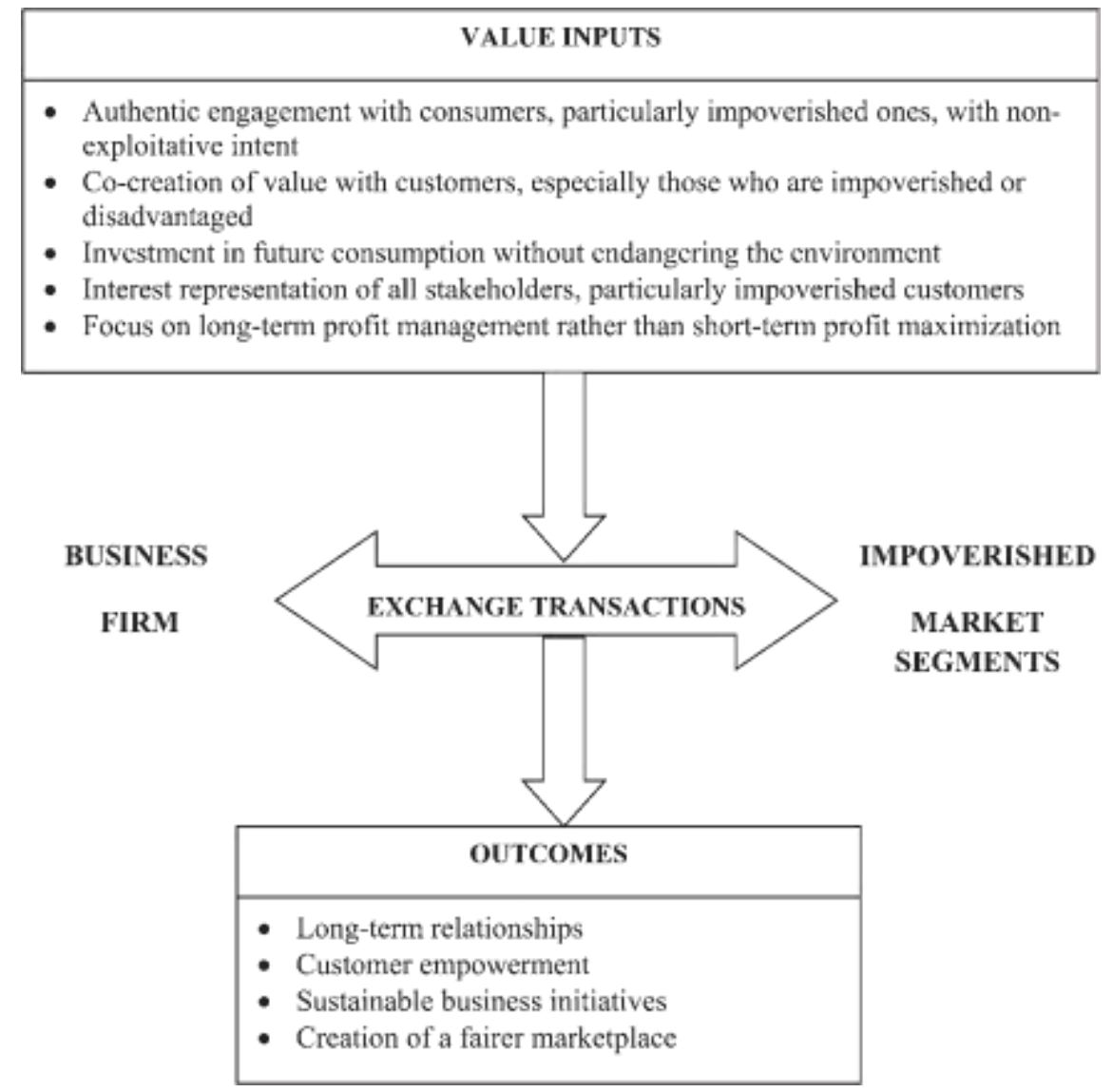

Journal of Catholic Social Thought, Vol 13, No. 1 (Winter 2016): pg. 63-81. DOI. This article is @ Philosophy Documentation Center and permission has been granted for this version to appear in e-Publications@Marquette. Philosophy Documentation Center does not grant permission for this article to be further copied/distributed or hosted elsewhere without the express permission from Philosophy Documentation Center. 